surgeons, one of whom, Rivolta, wrote about the disease in 1868. In Germany Bollnger rediscovered it in 1877, and gave it the name by which it is at present known. Israel was the first to describe a case of it in a man in 1878 , but since then several cases of the disease have been published on the Continent and two or three in this country.

Lincoln.

\section{A CASE OF}

\section{SEPARATION OF THE UPPER EPIPHYSIS} OF THE LEFT FEMUR.

BY A. W. MAYO ROBSON, F.R.C.S.,

SURGEON TO THE LEEDS GENERAL INFIRMARY, LECTURF ON OPERATIVE SURGERY AT THE YORKSHIRE COLLEGK.

IN the article by Mr. H. Morris in Holmes' System of Surgery occurs the following passage:--"Several supposed examples of this accident have been recorded, but I agrea with $\mathrm{Mr}$. Holmes in thinking that they are not conclusive as to the real existence of this lesion," and again in the same page, "fractures of the neck of the femur are hardly known in childhood, and the upper epiphysis is so small and lies so completely within the hip-joint, that its disjunction is unknown, except perhaps in the foetus." The case related below is certainly either a fracture through the neck of the femur or a separation of the upper epiphysis; I believe it to be the latter, and in this opinion I am supported by $\mathrm{my}$ colleagues at the Leeds Infirmary, to whom I showed the patient. The notes have been furnished by my dresser, Mr. Roper.

W. C-, aged five, was admitted in March, 1886, into the Leeds General Infirmary on account of lameness due to

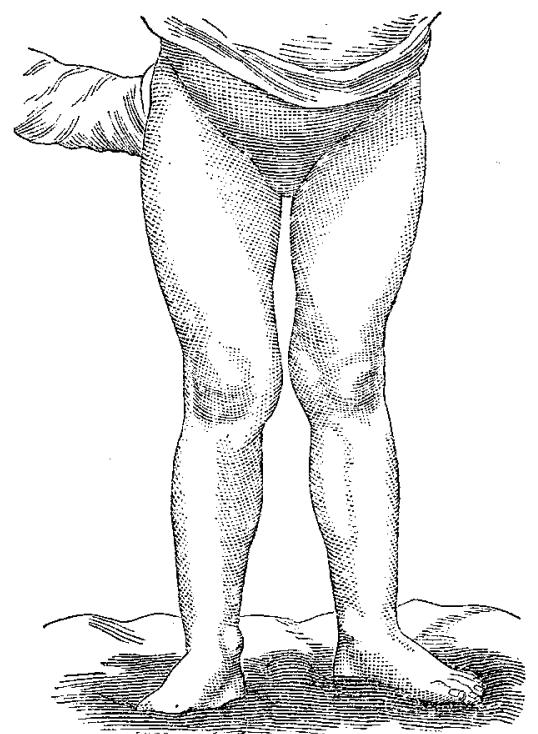

shortening of the left lower extremity, with the history of having been thrown up four years previously by her uncle, who failed to catch her, letting her fall heavily on the left side. Beyond rest no treatment had been followed out, and the mother was unaware of any other accident having happened to the child, but she had noticed the limp to become more marked during the last few months.

The accompanying photograph, kindly taken for me by Mr. Barling, clearly shows the position of the deformed left limb as the patient stood. The signs on admission were as follows:-Marked limp on walking, the patient leaning to the left; well-marked eversion of the foot, which could, however, be brought parallel with the right without giving pain; ability to completely flex and extend the thigh. Measurement from the anterior superior spine of the ilium to the malleolus showed three-quarters of an inch of shortening on the left side, and from the same point to the lower border of the patella gave a like result, but the distance from the top of the great trochanter to the malleolus was the same on both sides. Nélaton's line showed the left great trochanter to be raised three-quarters of an inch, and Bryant's line was three-quarters of an inch shorter on the injured side. The folds of the buttocks were well marked. On flexing and rotating inwards the left femar the fingers could clearly feel the neck of the femur as far as the head, but the prominent part of the caput femoris was apparently in the acetabulum, and was not attached to the cervix. The muscles of the limb were well developed, and a thickened sole on the left boot almost abolished the limp. Leeds.

\section{A a tellitror}

\section{OF}

\section{HOSPITAL PRACTICE, BRITISH AND FOREIGN.}

Nulla autem est alia pro certo noscendi via, nisi quamplurimas et morborum et dissectionum historias, tum aliorum tum proprias collectas habere, et inter se comparare.-MorGAGNI De Sed. et Caus. Morb., lib. iv. Procmium.

\section{UNIVERSITY COLLEGE HOSPITAL.}

IMPACTION OF A FOREIGN BODY IN THE CESOPHAGUS; LARYNGOTOMY ; TRACHEOTOMY ; RECOVERY ; REMARKS.

(Under the care of Mr. CHRISTOPHeR HEATH.)

THE following is one of a class of cases which not unfrequently present themselves in the casualty department of large hospitals, and in which the necessity for immediate interference is imperative. With a history such as that given, after exploration of the pharynx without the discovery of any foreign body, the indication is clearly the line of treatment adopted in this case, the completion of the diagnosis being left until the subsidence of the urgent symptoms. There are few conditions in which a more prompt action or greater self-reliance is required. For the following notes we are indebted to Mr. Hugh Armstrong, house-surgeon.

On May 22nd, W. S_- a boy aged twelve, was brought to University College Hospital casualty room by the father, with the history that while at dinner the boy had fallen back choking. When seen by the house-surgeon the patient was insensible, motionless, much cyanosed, and making strong inspiratory efforts that appeared to draw a small quantity of air into the lungs. Nothing could be felt at the back of the mouth; and, as the case was extremely urgent, laryngotomy was performed with a penknife, and the opening in the crico-thyroid membrane kept patent with a pair of sinus forceps. There was a little bleeding, chiefly venous, which subsided as soon as the asphyxial condition was relieved. The opening, however, did not seem sufficient, so tracheotomy was done, and a tube tied in, the cricoid cartilage not being divided. The boy quickly recovered consciousness, and in about a quarter of an hour was taken into a private ward, put under chloroform, and examined. Nothing could be felt in the fauces or pharynx with the finger. A No. 6 English catheter was then passed along the forefinger down the pharynx, and, when about two-thirds had disappeared, an obstruction was felt, beyond which the instrument would not pass; for it doubled up when moderate pressure was made. A full-sized instrument with a stylet in it was next tried. The obstruction was again felt, and, after somewhat firmer pressure, the catheter slipped on into the stomach. There was no blood on the end of the instrument when withdrawn. A feather was afterwards passed up the larynx through the tracheotomy opening, but no obstruction felt. The tube was replaced, a canopy arranged over the bed, and steam allowed to play under it. While recovering from chloroform the boy vomited a large piece of meat an inch and a half long, three-fourths of an inch broad, and about half an inch thick; and when quite conscious gave the house-surgeon to understand that the obstruction had disappeared. Milk and beef-tea were ordered. The temperature rose to $102^{\circ}$ on the following evening, but never went higher. A piece of wet boracic lint was laid over the mouth of the tube, which was kept in for forty-eight hours. When this was withdrawn the wound was covered with wet lint, and by June 8th had completely closed. The boy's voice had regained its strength within a week later.

The after-treatment consisted in keeping the air of the room warm and moist, but the steam kettle was removed on the second day, when the temperature was $102^{\circ}$. No crepitation could be heard over any part of the chest, and the pulse respiration ratio was unaltered.

Remarks.-The exact cause of the asphyxia in this case is 